\title{
FEATURES OF THE CLINICAL COURSE OF ACUTE OTITIS MEDIA IN PATIENTS WITH IMPAIRED CARBOHYDRATE METABOLISM
}

\author{
Tatiana Pochuieva \\ Department of Otorhinolaryngology and Pediatric Otolaryngology ${ }^{1}$ \\ Anna Filatova $\bowtie$ \\ Department of Otorhinolaryngology and Pediatric Otolaryngology ${ }^{1}$ \\ ane4kafilatova@ukr.net \\ Iryna Filatova \\ Department of Otorhinolaryngology and Pediatric Otolaryngology ${ }^{l}$ \\ ${ }^{1}$ Kharkiv Medical Academy of Postgraduate Education \\ 58, Amosov str., Kharkiv, Ukraine, 61176
}

$\triangle$ Corresponding author

\begin{abstract}
The aim of the research: study of the features of the clinical course of acute otitis media (AOM) in patients with impaired carbohydrate metabolism.

Materials and methods. We examined 140 patients with AOM aged 19 to 72 years, of which 75 patients with impaired carbohydrate metabolism constituted the main group and 65 patients were included in the comparison group. Taking into account the peculiarities of the pathogenesis of AOM and disorders of carbohydrate metabolism, patients were randomized into 4 groups: 1 - patients with AOM (36), 2 - patients with AOM on the background of sinusitis (29), 3 - patients with AOM on the background of non-insulin-dependent diabetes mellitus (DM type II) (37), 4 - AOM patients with impaired glucose metabolism (38). The patients underwent a general clinical examination, determination of glycosylated hemoglobin, leukocyte indices of intoxication, audiometry, computed tomography (CT) of the temporal bones (if indicated).

Results. The proportion of patients with impaired carbohydrate metabolism in 2020 was $32.6 \%$, of which DM type II was diagnosed in $49.3 \%$ earlier. It was shown that a feature of the clinical course of AOM against the background of impaired carbohydrate metabolism is the discrepancy between the duration of the disease history, complaints and objective data to the state of the cellular structure of the mastoid process according to CT data and impaired auditory function mainly by the type of sound perception, which indicates the formation of latent mastoiditis. Clinically significant complaints and objective data for the differential diagnosis of latent mastoiditis in these patients were determined. The absence of statistical significance of differences in indicators in patients with DM type II and against the background of transient hyperglycemia was revealed, and the concept of the latter was characterized. A direct correlation between blood glucose levels and glycated hemoglobin levels was established in patients with DM type II and AOM.

Conclusions. DM type II creates a favorable background for the formation of the clinical course of AOM complicated by latent mastoiditis.

From the general contingent of patients with AOM, patients should be distinguished not only with DM type II, but also with transient hyperglycemia for its timely diagnosis. Significant symptoms: pain and a feeling of «heaviness» in the behind-the-ear region in the absence of reactive phenomena, a feeling of «pulsation» in the ear, dizziness, a cloudy eardrum with a protrusion or perforation in the posterior or posterior-upper section, an asymmetric increase in sound perception thresholds above $25 \mathrm{~dB}$. Such patients should be observed with «early» CT scan of the temporal bones.
\end{abstract}

Keywords: acute otitis media, non-insulin dependent diabetes mellitus, latent mastoiditis, transient hyperglycemia, audiometry.

DOI: $10.21303 / 2504-5679.2022 .002280$

\section{Introduction}

The choice of the subject of this study is due to our earlier data on the significance of hyperglycemia for the formation of a complicated course of acute otitis media (AOM). We found that for the period 2018-2020, $72.9 \%$ of intracranial complications were secondary otogenic meningitis in patients with acute otitis media against the background of hyperglycemia. Of these, $40.5 \%$ of 
patients had previously diagnosed type 2 diabetes mellitus, and in $32.4 \%$, diabetes mellitus manifested as a complicated course of acute otitis media [1].

According to the literature, acute otitis media is a common pathology in children and adults, accounting for $2.5 \%$ of all diseases of the human body [2]. Among ear diseases, the proportion of AOM increases to $30 \%$ or more $[2,3]$. The social significance of AOM lies in the possibility of developing against its background various complications [4, 5] and a negative impact on auditory function $[6,7]$. The main etiological factors and pathogenetic links of acute otitis media have been studied and are being studied: tubal dysfunction [8,9], the role of the microbial factor [10,11], disorders in the system of general and local immunity [12], pathology of the attic and morphological changes in the tissues of the mastoid process and snails $[2,13]$. The data of modern studies indicate the features of the clinical and pathogenetic course of acute otitis media with the threat of sensorineural hearing loss [2], latent mastoiditis [14], which are somewhat different from the classical approach. Methods for diagnosing and treating secretory otitis media are being improved [15].

Clinical and pathogenetic features of ENT diseases, in particular otiatric pathology, in conditions of comorbidity with diabetes mellitus are being actively studied $[16,17]$. Variants of the clinical course of inflammatory diseases of soft tissues (furuncle, phlegmon of the neck), pharynx (tonsillitis, paratonsillar and parapharyngeal obscesses) [18, 19], paranasal sinuses [20], features of sensorineural hearing loss in otolaryngological patients on the background of non-insulin-dependent diabetes mellitus (DM type II) are described [17]. The pathogenetic significance of non-insulin dependent diabetes mellitus for the formation of a special form of otitis externa, the socalled malignant otitis externa, has been shown in numerous publications [21, 22]. A feature of the clinical course of the disease is the involvement in the inflammatory process of the bone structures of the middle ear (purulent otitis media and mastoiditis) [23] and the pyramid of the temporal bone with the formation of osteomyelitis [24, 25]. The background effect of diabetes mellitus is manifested by the tendency of patients to develop purulent infections and complications [26], changes in bone structures with a decrease in bone mineral strength [27, 28].

The above theoretical prerequisites and our data on the pathogenetic significance of hyperglycemia for the development of a complicated course of AOM determine the relevance of this study.

The aim of the research: study of the features of the clinical course of AOM in patients with impaired carbohydrate metabolism.

\section{Materials and methods of the research}

The study was conducted based on a specialized otolaryngological clinical hospital Municipal non-profit enterprise «City Clinical Hospital No. 30» of the Kharkiv City Council.

The design of the study (Fig. 1) at the first stage involved the study of statistical indicators for the period 2018-2021 for the main diagnosis of acute otitis media (code H 65.0 according to ICD-10), followed by determining the proportion of patients with impaired carbohydrate metabolism. Considering the obtained statistical data, 2020 was chosen as the period for conducting the main array of studies. At the same time, we proceeded from the fact that in the conditions of an unfavorable epidemiological situation, the proportion of «unreasonable» applications is significantly reduced. When selecting patients for the study, we took as a basis, first of all, the number of patients with impaired carbohydrate metabolism, distributing patients with AOM into the comparison group according to the random sampling method upon admission to the hospital in the amount necessary to form representative groups.

Criteria for inclusion of patients in the study: patients with AOM older than 18 years of age with impaired carbohydrate metabolism, patients with AOM older than 18 years without impaired carbohydrate metabolism. When diagnosing AOM, the diagnostic criteria indicated by A. L. Kosakovsky and F. B. Yurochko (2016) were used.

Criteria for exclusion of patients from the study: patients under 18 years, pregnant women, patients with other forms of otitis, including those previously operated on the middle ear, patients with comorbidities (alcoholism, drug addiction, tuberculosis, oncological diseases), which could distort the results of the examination. 


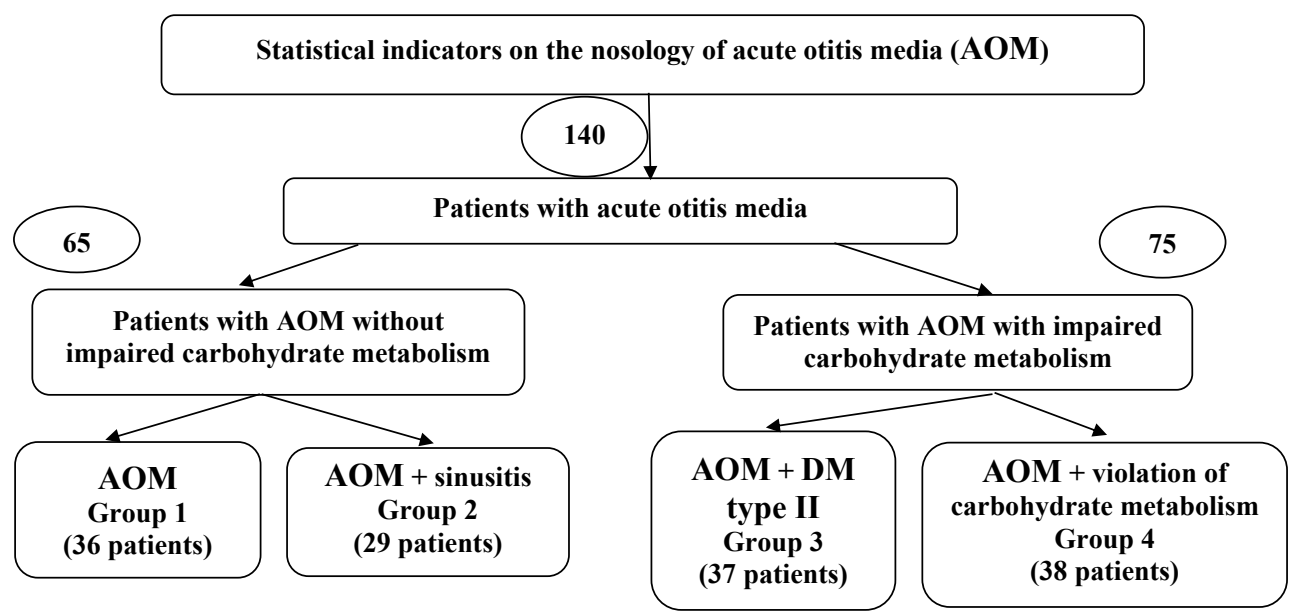

Fig. 1. Study design outline

Considering the pathogenesis of AOM and the characteristics of carbohydrate metabolism disorders, all patients were randomized into 4 groups:

Group 1 - patients with AOM (36 patients).

Group 2 - patients with AOM against the background of acute or exacerbation of chronic sinusitis (29 people).

Group 3 - patients with AOM on the background of non-insulin dependent diabetes mellitus (37 patients).

Group 4 - patients with AOM on the background of carbohydrate metabolism disorders (38 people).

All study participants provided voluntary informed consent. The work was carried out in accordance with the Code of Ethics of the World Medical Association (Declaration of Helsinki). The Committee of the Commission of the Kharkiv Medical Academy of Postgraduate Education on Bioethics approved and approved protocol No. 4 dated November 18, 2021.

Under the violation of carbohydrate metabolism meant the presence and (or) a combination of several factors: hyperglycemia at admission or during treatment, the presence of glucose in the urine or albuminuria, aggravated anamnesis, the presence of a certain concomitant pathology (hypertension, obesity, fatty hepatosis, dyscirculatory encephalopathy, angiopathy, neuropathy).

All patients underwent a general clinical examination: history taking, general examination and examination of ENT organs, clinical blood and urine tests, determination of blood glucose and glycosylated hemoglobin levels. Leukocyte indices (shift index - SI, leukocyte index of intoxication (LII) Kalf-Kalif and Ostrovsky, reactive neutrophils response (RNR)) according to generally accepted formulas, they were calculated on a leukocyte index calculator. Glycosylated hemoglobin was determined by the ion exchange method using a High Technology reagent kit (HT-G130-80).

According to the indications, a computer study of the pyramids of the temporal bones was performed (in most cases - spiral computed tomography and, in isolated cases, MRI). The study of auditory function (acumetry, audiogram) was performed according to the generally accepted method on the audiometer AD629 No. 098076 (Denmark), certificate No. 22-01/22302.

Statistical processing of the obtained results was carried out using the program Statistica 13/0 (StatSoft, USA license number JPZ8041382130ARCN10-J). Quantitative data are presented as mean $(\mathrm{M})$ and standard deviation $(+\mathrm{SD})$. Student's t-test was used to compare values between groups. Differences were considered significant at $p<0.05$.

\section{Research results}

In total, for the period 2018-2021, 19960 patients over 18 years old were treated in the hospital, of which 1328 patients were diagnosed with acute otitis media, which accounted for $6.65 \%$ of all nosological forms of ENT diseases (Table 1). 
Table 1

Statistical indicators of acute otitis media

\begin{tabular}{cccccc}
\hline \multirow{2}{*}{ Year of study } & \multicolumn{3}{c}{ Total patients } & \multicolumn{2}{c}{ Patients with acute otitis media } \\
\cline { 2 - 6 } & Number & \% of total & Number & \% & \% of acute otitis media of the total number of ear diseases \\
\hline 2018 & 5890 & 29.5 & 360 & 6.2 & 27.1 \\
2019 & 5549 & 27.8 & 402 & 7.2 & 30.3 \\
2020 & 3614 & 18.1 & 230 & 6.4 & 17.3 \\
2021 & 4907 & 24.6 & 336 & 6.8 & 25.3 \\
Total for the study period & 19960 & 100 & 1328 & 6.65 & 100
\end{tabular}

It should be noted that against the background of the unfavourable impact of the epidemiological situation in Ukraine and with a decrease in the total number of patients in the ENT hospital in 2020, the proportion of patients with AOM did not decrease, amounting to $6.4 \%$ compared to $6.2 \%$ in 2018. The proportion of acute otitis media among all ear diseases was significantly higher and ranged from $17.3 \%$ to $30.3 \%$. At the same time, the proportion of patients with impaired carbohydrate metabolism in 2020 was $32.6 \%$, of which $49.3 \%$ were diagnosed with type 2 diabetes mellitus before the present disease.

The distribution of patients by sex (A) and age (B) is shown in Fig. 2.

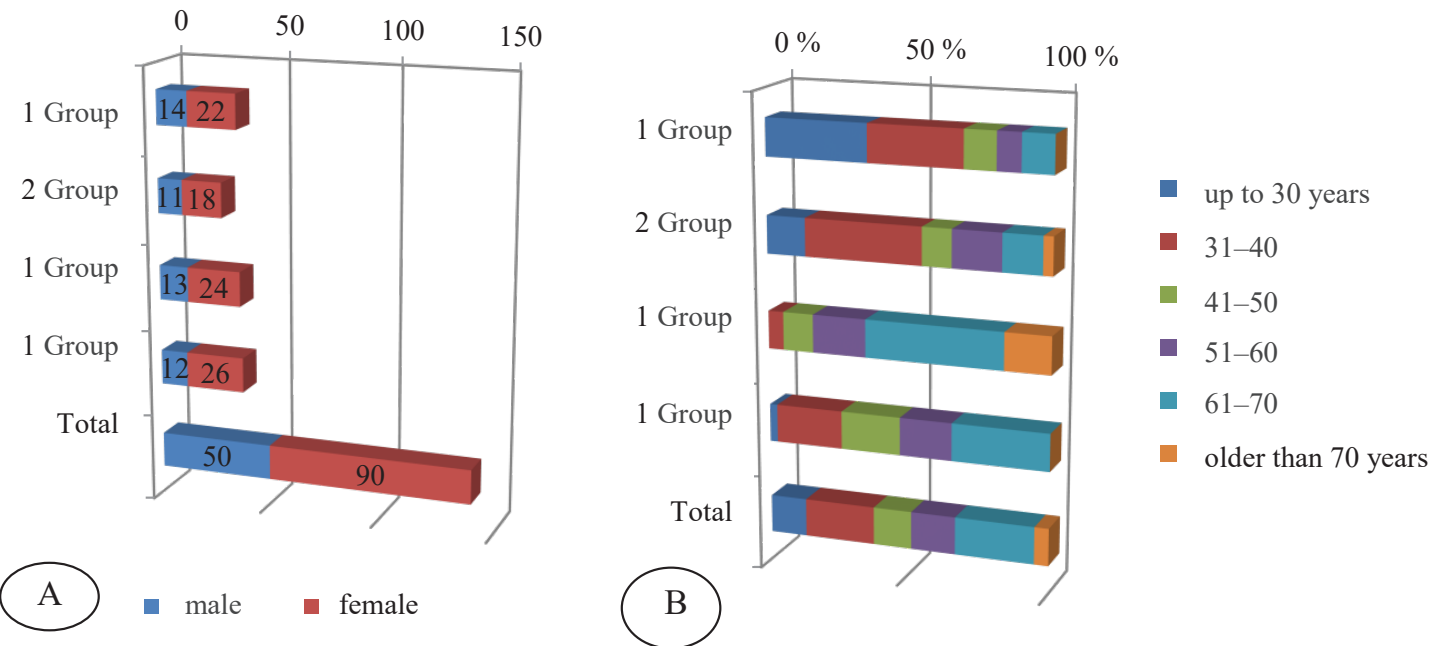

Fig. 2. Distribution of patients in groups by sex and age

In general, there was a predominance of females (1:1.8) with an equal frequency in the absence of carbohydrate metabolism disorders (1:1.6) in groups 1 and 2 and a maximum predominance in group 4 (1:2.2). Differences were also found in the age composition of patients with an increase in the proportion of younger patients from 19 to 40 years old in the absence of carbohydrate metabolism disorders (63.1\%) in groups 1 and 2 and older patients from 51 to 70 years old in groups 3 and 4 .

When determining the history of the disease (Fig. 3), it was found that early treatment (up to 7 days) was characteristic, first of all, for patients of the 2nd group against the background of the main pathogenetic factor in the development of AOM - sinusitis (62.1\%) and for patients with AOM against the background of DM type II (48.6\%).

Patients of the 1st group (30.5\%) and patients of the 4th group (36.8\%) applied with almost equal frequency up to 7 days of illness. In terms of up to 14 days, $52.8 \%$ of patients of the first, $44.7 \%$ of patients of the fourth, $34.5 \%$ of the second and $21.6 \%$ of patients of the third groups applied for specialized care. In some patients with impaired carbohydrate metabolism (27.9\% in the 3 rd group and $18.2 \%$ in the 4 th group), the history of the disease was longer and ranged from 14 days to 3 months. It should be noted that with an in-depth study of the anamnesis in patients 
of the 3rd and 4th groups who applied early (up to 7 days), there were transient episodes of pain «severity» - hearing loss in the period from 10-14 days to 1-2 months prior to this application. And only in the presence of persistent symptoms, according to patients, «acute», they applied or were referred by a family doctor for specialized care.

It should be noted that an aggravated history (presence of diabetes mellitus in close relatives) was established in 1 patient of the 1st group, 4 patients of the 2 nd group, in $13(35.1 \%)$ and 11 patients $(28.9 \%)$ of the 3 rd and 4 th groups, respectively.

The main complaints of patients are shown in Fig. 4.

Similar complaints in patients of all groups were: hearing loss $(100 \%, 72.2 \%, 84.1 \%$, $94.7 \%$ in the first, second, third and fourth groups, respectively), ear pain (50\%, $65 \%, 64.9 \%$, $68.4 \%$, respectively, in groups), noise in the ear $(30.6 \%, 27.6 \%, 37.8 \%$ and $34.2 \%$ of patients in the first, second, third and fourth groups, respectively).

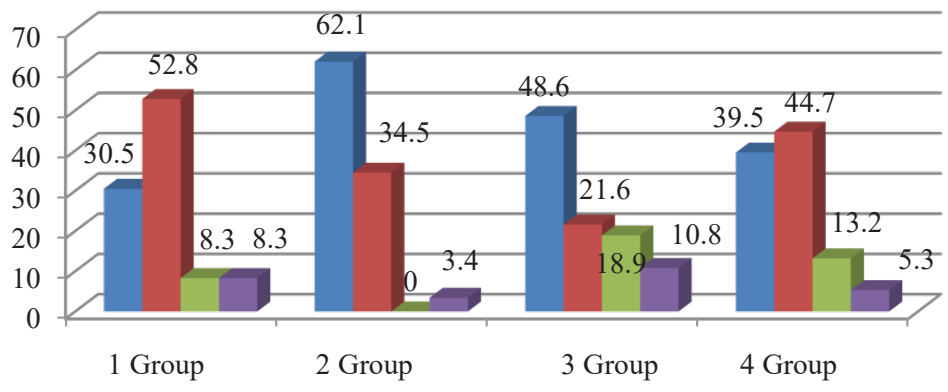

- Up to 7 days $(\%)$

- Up to 14 days (\%)

- Up to 30 days $(\%)$

- More than 30 days

Fig. 3. Duration of medical history in patients with AOM

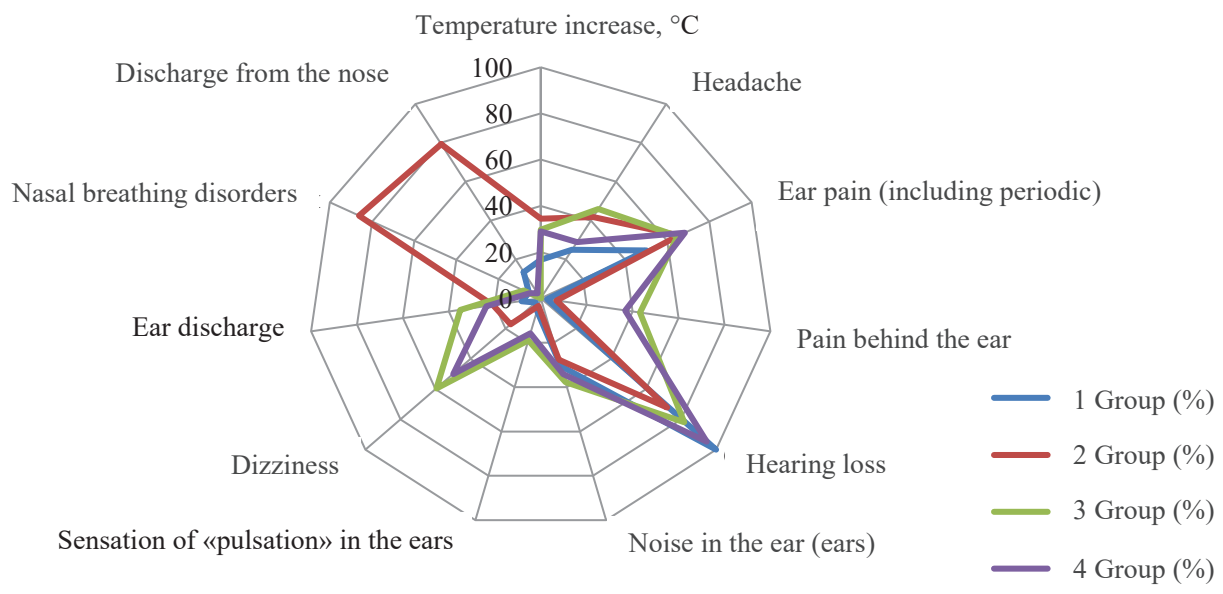

Fig. 4. The structure of the main complaints in patients with AOM

A large proportion of complaints about nasal breathing disorders $(86.2 \%)$ and nasal discharge $(73.9 \%)$ in patients of the second group is due to the main pathogenetic factor of AOM sinusitis. In patients with impaired glucose metabolism, the proportion of complaints of pain in the behind the ear (including periodic), a feeling of «heaviness» in the behind the ear in $43.2 \%$ of patients in the third and in $36.8 \%$ of patients in the fourth group versus $2.8 \%$ and 6.95 in the 1 st and 2nd groups, respectively. The significance of complaints about «pulsation» in the ear also increased $(18.9 \%$ and $15.8 \%$ in the 3 rd and 4 th groups versus $5.6 \%$ and $3.4 \%$ in the 1 st and 2 nd groups), dizziness (59.5\% and $50 \%$ in patients with DM type II and in group 4 versus $2.8 \%$ and $17.2 \%$ in groups 1 and 2). Characteristically, $44.7 \%$ (17 patients) of patients of the 4th group on the eve of admission had a single «unmotivated» increase in body temperature up to $38-39{ }^{\circ} \mathrm{C}$.

When performing otoscopy (Fig. 5) as the main criterion for AOM in patients with impaired carbohydrate metabolism, hyperemia and infiltration of the tympanic membrane were visualized with almost equal frequency (unlike patients of the 1st and 2nd groups) with virtually no identifying 
contours (45.8 \% and $44.7 \%$ against the background of DM type II and in groups 4-1), thickened cloudy eardrum with fuzzy identification contours (48.5\% and $47.4 \%$ in groups, respectively). Different from patients of the 1st and 2nd groups was «atypical» bulging of the tympanic membrane in the posterior or postero-superior sections (A, C) in $44.4 \%$ and $36.8 \%$ of cases in patients of the third and fourth groups, which is against the background of an increase in body temperature during referral to inpatient treatment was erroneously interpreted as a manifestation of viral (bullous) otitis media. In $18.9 \%$ of patients with DM type II, who noted the appearance of discharge in the ear canal, the presence of perforation of the tympanic membrane of atypical localization in the posterior or posterior-upper section was diagnosed (B, C, D).
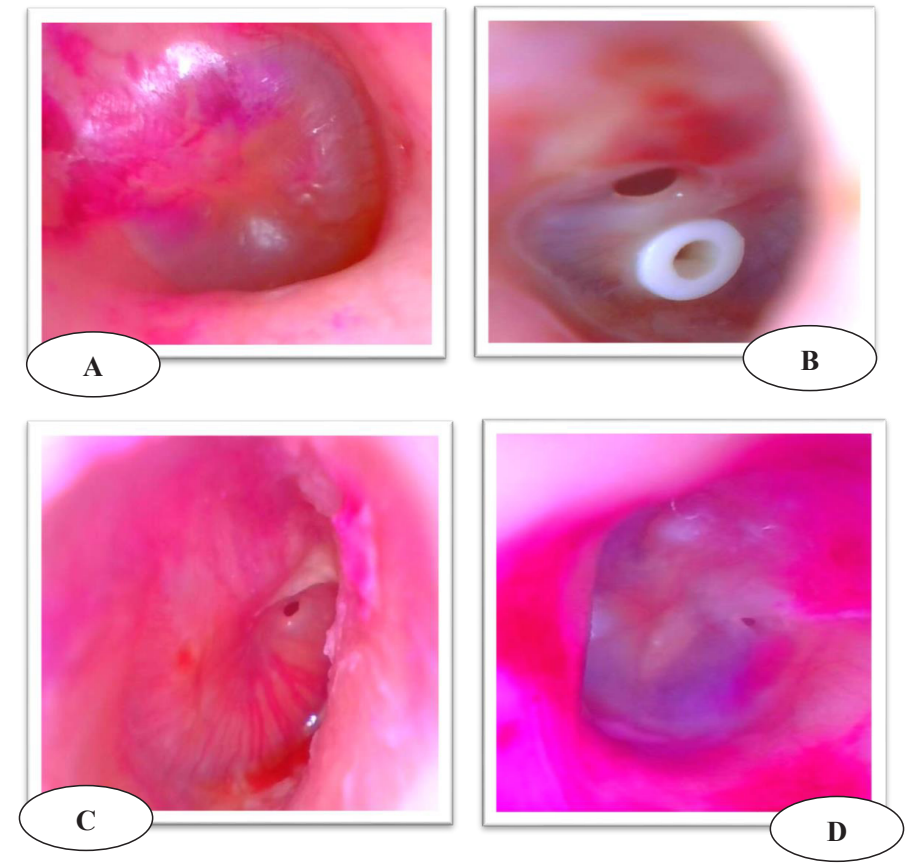

Fig. 5. Features of the otoscopic picture

Concomitant pathology in the examined group of patients was a certain comorbid background, different in patients in groups. So, in the first group, comorbid pathology was established in $33.3 \%$ of cases and consisted mainly in manifestations of angiodystonia and asthenic syndrome. In the second group, the comorbid background was detected in $48.3 \%$ of patients, and against the background of impaired carbohydrate metabolism, it was significantly higher and concomitant pathology was diagnosed in $63.2 \%$ of patients in the fourth group, and in $75.7 \%$ of patients with DM type II. Among the comorbid pathologies in patients with impaired carbohydrate metabolism, the following were noted: dyscirculatory encephalopathy, retinal angiopathy, hypertension, coronary heart disease, cardiosclerosis, polyneuropathy, osteochondrosis, vestibulo-atactic and cerebrosthenic syndrome, obesity.

Comparative characteristics of the morphological composition of peripheral blood are shown in Table 2.

Although, in general, the indicators are within acceptable limits, a statistically significant increase in the content of leukocytes in patients of the 4th group was determined in comparison with patients with DM type II $(p<0.05)$. In patients of the $3 \mathrm{rd}$ and 4 th groups, a decrease in the content of eosinophils was found compared to that of patients in the 1st and 2nd groups, which was statistically significant in patients with DM type II $(p<0.05)$. At the same time, against the background of impaired glucose metabolism in patients of the 4th group, the content of monocytes decreased statistically significantly compared with the 3 rd $(p<0.001)$ and 2 nd $(p<0.05)$ groups.

Selectively, in patients of all four groups, the content of glycated hemoglobin in the blood was determined (Table 3). 
Table 2

Morphological composition of peripheral blood in patients with AOM

\begin{tabular}{lcccccccccc}
\hline Group & $\begin{array}{c}\text { Red blood } \\
\text { cells } \\
(\mathbf{x 1 0 1 2 / l )}\end{array}$ & $\begin{array}{c}\text { Hemo- } \\
\text { globin (g/l) }\end{array}$ & $\begin{array}{c}\text { Leuko- } \\
\text { cytes } \\
\mathbf{( 1 0 9 / l )}\end{array}$ & $\begin{array}{c}\text { P/nuc- } \\
\text { lear (\%) }\end{array}$ & $\begin{array}{c}\text { C/nuc- } \\
\text { lear (\%) }\end{array}$ & $\begin{array}{c}\text { Eosino- } \\
\text { phils (\%) }\end{array}$ & $\begin{array}{c}\text { Lympho- } \\
\text { cytes (\%) }\end{array}$ & $\begin{array}{c}\text { Mono- } \\
\text { cytes (\%) }\end{array}$ & $\begin{array}{c}\text { ESR } \\
(\mathbf{m m} / \mathbf{h})\end{array}$ & $\begin{array}{c}\text { Blood } \\
\text { glucose } \\
\text { (mmol/l) }\end{array}$ \\
\hline Group 1 & $4.2 \pm 0.07$ & $132.2 \pm 2.5$ & $8.4 \pm 0.6$ & $5.2 \pm 0.35$ & $62.2 \pm 1.6$ & $2.7 \pm 0.3$ & $22.76 \pm 1.5$ & $7.32 \pm 0.5$ & $14.9 \pm 2$ & $4.9 \pm 0.1$ \\
$(n=36)$ & $(3.1-4.9)$ & $(101-165)$ & $(4-17.2)$ & $(1-10)$ & $(40-91)$ & $(0-6)^{* *}$ & $(5-51)$ & $(2-12)$ & $(2-46)$ & $(3.4-6)^{* * * *}$ \\
Group 2 & $4.3 \pm 0.06$ & $133.3 \pm 2.2$ & $7.8 \pm 0.5$ & $4.9 \pm 0.5$ & $63.03 \pm 1.2$ & $2.6 \pm 0.3$ & $22.14 \pm 0.97$ & $7.8 \pm 0.5$ & $17 . \pm 2.03$ & $5.1 \pm 0.1$ \\
$(n=29)$ & $(3.6-5)$ & $(108-158)$ & $(4-14.6)$ & $(1-11)$ & $(47-78)$ & $(1-6)^{* *}$ & $(13-34)$ & $(2-12)^{* * *}$ & $(3-45)$ & $(3.9-5.9)^{* * * * *}$ \\
Group 3 & $4.4 \pm 0.09$ & $134 \pm 2.9$ & $7.3 \pm 0.43^{*}$ & $5.7 \pm 0.4$ & $61.5 \pm 1.3$ & $1.7 \pm 0.2$ & $22.57 \pm 1.2$ & $8.7 \pm 0.43$ & $18.03 \pm 2.5$ & $8.8 \pm 0.6$ \\
$(n=37)$ & $(3-5.5)$ & $(100-174)$ & $(3.4 \pm 14.2)$ & $(1-9)$ & $(45-79)$ & $(0-5)^{* *}$ & $(10-36)$ & $(3-15)^{* * *}$ & $(2-55)$ & $(3.4-19)^{* * * *}$ \\
Group 4 & $4.2 \pm 0.07$ & $127.2 \pm 2.9$ & $8.9 \pm 0.5 *$ & $6.2 \pm 0.6$ & $65.5 \pm 1.5$ & $1.9 \pm 0.3$ & $19.9 \pm 0.9$ & $6.3 \pm 0.5$ & $18.8 \pm 2.5$ & $6.7 \pm 0.09$ \\
$(n=38)$ & $(3.2-5.4)$ & $(100-159)$ & $(4.4-16.5)$ & $(1-18)$ & $(46-86)$ & $(0-9)$ & $(7-33)$ & $(1-14)^{* * *}$ & $(2-64)$ & $(5.9-8.2)^{* * * * *}$
\end{tabular}

Note: * - reliability of differences in indicators of 3-4 groups $(p<0.05) ; * *$ - reliability of differences in indicators of $1-3$ and 2-3 groups $(p<0.05) ; * * *-$ reliability of differences in indicators of 2-4 and 3-4 groups $(p<0.05) ; * * * *-$ reliability of differences in indicators of $1-4,2-4$ groups $(p<0.001)$ and $3-4$ groups $(p<0.01)$

Table 3

The content of glycosylated hemoglobin in the blood serum of patients with AOM

\begin{tabular}{ccccc}
\hline Indicator & Group 1 $(\boldsymbol{n}=\mathbf{1 7})$ & Group 2 $(\boldsymbol{n}=\mathbf{1 5})$ & Group 3 $(\boldsymbol{n}=\mathbf{2 0})$ & Group 4 (n=21) \\
\hline Blood glucose (mmol/l) & $4.8 \pm 0.2$ & $5.0 \pm 0.18$ & $10.7 \pm 0.8$ & $6.8 \pm 0.15$ \\
& $(3.4-6.0)^{* * *}$ & $(3.9-6.0)^{* * * * * * *}$ & $(4.2-15.6) * * * * *$ & $(5.2-8.2)$ \\
Glycosylated hemoglobin (\%) & $4.9 \pm 0.2$ & $4.8 \pm 0.2$ & $9.8 \pm 0.5$ & $8.01 \pm 0.2$ \\
& $(3-6.3)^{* * *}$ & $(3.8-6.0)^{* * * * * * *}$ & $(6.9-13.1) * * * *$ & $(6.8-9.5)$
\end{tabular}

Note: * - reliability of differences in indicators of groups $1-3(p<0.001) ; * *$ - reliability of differences in indicators of groups 1-4 ( $<<0.001) ; * * *$ - reliability of differences in indicators of groups $2-3(p<0.001) ; * * * *$ reliability of differences in indicators of groups 2-4 $(p<0.001) ; * * * * *$ - reliability of differences in indicators of groups $3-4(p<0.05)$

As in the groups as a whole (Table 2), there was a significant difference in blood glucose levels in groups $1-3,1-4,2-3,2-4$, in the absence of a statistical difference between groups 1 and 2 , which indicates the correct choice of patient population. The content of glycosylated hemoglobin corresponded to the glucose values in the groups with the same reliability. The study of the correlation established the presence of a strong correlation between the level of glucose in the blood serum and the content of glycosylated hemoglobin $(R=0.8)$ in patients with DM type II and a weak correlation between the indicators in patients of the 4th group $(R=0.33)$.

According to the morphological composition of peripheral blood, the level of endogenous intoxication was studied by the value of leukocyte indices (Table 4).

Table 4

Leukocyte indices in patients with AOM

\begin{tabular}{ccccc}
\hline Group & Shift index & LII Kalf-Kalif & LII Ostrovsky & Reactive neutrophil response \\
\hline $\begin{array}{c}\text { Group 1 } \\
(n=36)\end{array}$ & $0.083 \pm 0.006(0.011-0.143)$ & $1.07 \pm 0.19(0.24-6.64)^{*}$ & $2.46 \pm 0.3(0.69-11.5)$ & $6.7 \pm 0.9(0.69-17.25)^{* *}$ \\
$\begin{array}{c}\text { Group 2 } \\
(n=29)\end{array}$ & $0.079 \pm 0.008(0.014-0.167)$ & $0.93 \pm 0.1(0.22-2.16)^{*}$ & $2.27 \pm 0.14(1.06-4)$ & $7.37 \pm 1.48(0.29-33)^{* * *}$ \\
$\begin{array}{c}\text { Group 3 } \\
(n=37)\end{array}$ & $0.094 \pm 0.007(0.01-0.18)$ & $1.2 \pm 0.1(0.33-2.63)$ & $2.29 \pm 0.14(1.02-4.05)$ & $11.91 \pm 1.5(0.67-33.63)^{* * * * * *}$ \\
$\begin{array}{l}\text { Group 4 } \\
(n=38)\end{array}$ & $0.1 \pm 0.01(0.01-0.31)$ & $1.45 \pm 0.15(0.23-3.67)^{*}$ & $2.88 \pm 0.2(1.09-6.69)$ & $12.95 \pm 1.8(1.28-45.39)^{* * * * *}$
\end{tabular}

Note: * - reliability of differences in indicators of 1-4 and 2-4 groups $(p<0.05) ; * *$ - reliability of differences in indicators of $1-3$ and $1-4$ groups $(p<0.001) ; * * *$ - reliability of differences in indicators of 2-3 and 2-4 groups $(p<0.01)$ 
A relative increase in LII Kalf-Kalif was found in the 3rd and 4th groups, which, although it did not indicate significant intoxication, was still significantly higher in patients of the 4th group $(p<0.05)$. Disturbance of carbohydrate metabolism in patients with AOM was accompanied by a significant $(p<0.001)$ increase in RNR in the 3rd and 4th groups compared with the 1st and with the indicators of patients of the 2 nd group $(p<0.01)$, despite the fact that there was no significant difference between the indicators of groups 1-2 and 3-4.

The analysis of auditory function in patients with AOM was performed according to the results of an audiometric study. The sound conduction function was evaluated by the level of air conduction in decibels at standard frequencies (Table 5).

\section{Table 5}

Air conduction in patients with AOM

\begin{tabular}{cccccccc}
\hline Group & $\mathbf{1 2 5} \mathbf{~ H z}$ & $\mathbf{2 5 0 ~ H z}$ & $\mathbf{5 0 0 ~ H z}$ & $\mathbf{1 0 0 0 ~ H z}$ & $\mathbf{2 0 0 0 ~ H z}$ & $\mathbf{4 0 0 0 ~ H z}$ & $\mathbf{8 0 0 0 ~ H z}$ \\
\hline \multirow{2}{*}{ Group 1 $(n=36)$} & $33.1 \pm 1.9$ & $32.72 \pm 1.75$ & $33.3 \pm 1.5$ & $37.2 \pm 1.9$ & $35 \pm 2.2$ & $43.06 \pm 2.5$ & $47.57 \pm 2.5$ \\
& $(10-60)^{* * *}$ & $(10-60)^{* * *}$ & $(20-55)^{* * *}$ & $(20-70)^{* * *}$ & $(20-80)^{* * *}$ & $(10-90)^{* * *}$ & $(10-80)^{* * *}$ \\
Group 2 $(n=29))$ & $32.9 \pm 2.9$ & $35.7 \pm 2.9$ & $38.3 \pm 3.18$ & $40.3 \pm 3.7$ & $38.2 \pm 3.7$ & $48.5 \pm 4.1$ & $48 \pm 4.1$ \\
& $(5-80)^{* * * * * * *}$ & $(5-80)^{* * * * * * *}$ & $(5-80)^{* * * *}$ & $(5-90)^{* * * *}$ & $(5-90)^{* * * * * * *}$ & $(5-90)^{* * *}$ & $(10-90)^{* * * *}$ \\
Group 3 $(n=37)$ & $43.25 \pm 2.6$ & $42.7 \pm 2.5$ & $43.65 \pm 2.8$ & $47.9 \pm 2.9$ & $49.46 \pm 3.2$ & $57.36 \pm 3.4$ & $58.3 \pm 3.7$ \\
& $(10-80)$ & $(10-75)$ & $(10-80)$ & $(10-90)$ & $(20-90)$ & $(20-90)$ & $(25-95)$ \\
Group 4 $(n=38)$ & $47.9 \pm 2.6$ & $46.58 \pm 2.7$ & $48.7 \pm 2.7$ & $52.8 \pm 3.1$ & $51.45 \pm 3.2$ & $58.66 \pm 3.4$ & $64.6 \pm 3.1$ \\
& $(20-80)$ & $(15-30)$ & $(20-100)$ & $(25-110)$ & $(20-110)$ & $(5-100)$ & $(30-95)$
\end{tabular}

Note: * - reliability of differences in indicators of groups $1-3(p<0.05)$; ** - reliability of differences in indicators of groups 1-4 $(p<0.05) ; * * *$ - reliability of differences in indicators of groups 2-3 $(p<0.05)$; **** - reliability of differences in indicators of groups $2-4(p<0.05)$

A significant $(p<0.05)$ increase in air sound perception thresholds was found in patients of the 3 rd and 4 th groups compared to patients without carbohydrate metabolism disorders. The exception is the absence of a statistically significant difference in sound conduction parameters at frequencies of 500, 1000 and $8000 \mathrm{~Hz}$ in patients of the 2nd and 3rd groups and at a frequency of $4000 \mathrm{~Hz}$ in patients of the 2nd and 4th groups $(p<0.05)$, which clearly shown in Fig. 6.

$125 \mathrm{~Hz} \quad 250 \mathrm{~Hz} \quad 500 \mathrm{~Hz} 1000 \mathrm{~Hz} 2000 \mathrm{~Hz} 4000 \mathrm{~Hz} 8000 \mathrm{~Hz}$

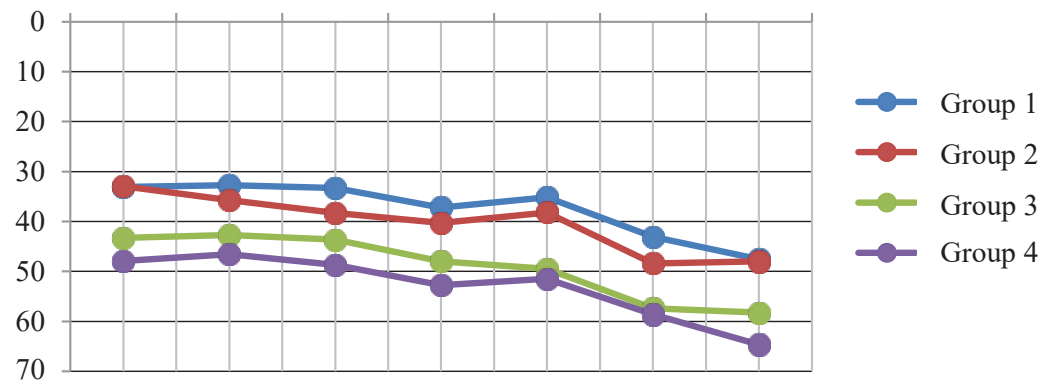

Fig. 6. Air conduction thresholds in patients with AOM

Sound perception was assessed by the level of bone conduction sound thresholds (Table 6).

A sharp deterioration in sound perception was noted against the background of a significant increase in the thresholds of bone conduction sounds $(p<0.001)$ at all frequencies in the 3 rd and, especially, in the 4th groups compared with patients without impaired carbohydrate metabolism (groups 1 and 2). At the same time, there was no significant difference in the thresholds of bone- and air-conducted sounds in patients of groups $1-2$ and 3-4 ( $p>0.05)$. Differences in indicators are illustrated in Fig. 7.

When performing a «routine» clinical diagnostic algorithm in patients with AOM, CT examination of the temporal bone pyramids is not mandatory and is performed taking into account individual indications. These include increased pain syndrome, the appearance of reactive phenomena, 
the ineffectiveness of conservative therapy, the absence or insufficient positive dynamics of the restoration of auditory function, the patient's refusal to perform diagnostic tympanopuncture. Considering these indications, the need for CT examination of the pyramids of the temporal bones arose in $48.6 \%$ of patients with DM type II and in $57.9 \%$ of patients with impaired carbohydrate metabolism of the 4th group, while CT was performed only in $2.7 \%$ of cases in patients of the 1 st and in $17.2 \%$ of patients of the 2 nd group. There were no destructive changes in the mastoid process in patients with impaired carbohydrate metabolism in any case. However, in all patients, a decrease in pneumatization of mastoid cells was found: filling of cells with a soft tissue component (inflammatory content) in the perianthral (20\%), perianthral and angular zones (30\%), total and subtotal filling of mastoid cells in $50 \%$ of cases (Fig. 8 A, B) with horizontal liquid levels in $25 \%$ of them.

Table 6

Bone conduction thresholds in patients with AOM

\begin{tabular}{|c|c|c|c|c|c|c|c|}
\hline Group & $125 \mathrm{~Hz}$ & $250 \mathrm{~Hz}$ & $500 \mathrm{~Hz}$ & $1000 \mathrm{~Hz}$ & $2000 \mathrm{~Hz}$ & $4000 \mathrm{~Hz}$ & $8000 \mathrm{~Hz}$ \\
\hline $\begin{array}{l}\text { Group 1 } \\
(n=36)\end{array}$ & $\begin{array}{c}6.67 \pm 0.7 \\
(0-20)^{*} * *\end{array}$ & $\begin{array}{c}8.3 \pm 0.6 \\
(0-15)^{* * *}\end{array}$ & $\begin{array}{c}9.6 \pm 0.98 \\
(0-35)^{* * *}\end{array}$ & $\begin{array}{l}11.1 \pm 0.87 \\
(0-20)^{* * *}\end{array}$ & $\begin{array}{c}15.8 \pm 1.3 \\
(0-40)^{* * *}\end{array}$ & $\begin{array}{l}18.75 \pm 1.7 \\
(5-50)^{* * *}\end{array}$ & $\begin{array}{c}18.7 \pm 1.4 \\
(5-40)^{* * *}\end{array}$ \\
\hline $\begin{array}{l}\text { Group 2 } \\
(n=29)\end{array}$ & $\begin{array}{c}9.5 \pm 1.3 \\
(0-30)^{* * * * * * *}\end{array}$ & $\begin{array}{c}10.7 \pm 1.4 \\
(0-40)^{* * * * * * *}\end{array}$ & $\begin{array}{c}11 \pm 1.5 \\
(0-40)^{* * * * * * *}\end{array}$ & $\begin{array}{c}12.8 \pm 1.8 \\
(0-50)^{* * * * * * *}\end{array}$ & $\begin{array}{c}17.6 \pm 2.5 \\
(0-60) * * * * * * *\end{array}$ & $\begin{array}{c}20 \pm 2.7 \\
(0-60)^{* * * * * * *}\end{array}$ & $\begin{array}{c}17.05 \pm 2.3 \\
(5-40)^{* * * * * * *}\end{array}$ \\
\hline $\begin{array}{l}\text { Group } 3 \\
(n=37)\end{array}$ & $\begin{array}{l}19.97 \pm 1.6 \\
(5-40)\end{array}$ & $\begin{array}{c}18.65 \pm 1.7 \\
(0-40)\end{array}$ & $\begin{array}{c}22.3 \pm 2 \\
(0-50)\end{array}$ & $\begin{array}{l}27.03 \pm 2.5 \\
(5-60)\end{array}$ & $\begin{array}{c}38.1 \pm 2.7 \\
(10-70)\end{array}$ & $\begin{array}{c}38.14 \pm 2.2 \\
(20-70)\end{array}$ & $\begin{array}{l}37.4 \pm 1.9 \\
(20-60)\end{array}$ \\
\hline $\begin{array}{l}\text { Group } 4 \\
(n=38)\end{array}$ & $\begin{array}{c}19.6 \pm 1.6 \\
(10-50)\end{array}$ & $\begin{array}{c}18.9 \pm 1.9 \\
(5-50)\end{array}$ & $\begin{array}{c}20.9 \pm 2.1 \\
(10-65)\end{array}$ & $\begin{array}{c}23.3 \pm 2.27 \\
(10-70)\end{array}$ & $\begin{array}{c}31.3 \pm 2.2 \\
(10-65)\end{array}$ & $\begin{array}{c}35.5 \pm 2.1 \\
(5-60)\end{array}$ & $\begin{array}{c}33.2 \pm 2.1 \\
(10-60)\end{array}$ \\
\hline
\end{tabular}

Note: * - reliability of differences in indicators of groups $1-3(p<0.001)$; ** - reliability of differences in indicators of groups 1-4 $(p<0.001) ; * * *$ - reliability of differences in indicators of groups $2-3(p<0.001)$; *** - reliability of differences in indicators of groups $2-4(p<0.001)$

$125 \mathrm{~Hz} 250 \mathrm{~Hz} 500 \mathrm{~Hz} 1000 \mathrm{~Hz} 2000 \mathrm{~Hz} 4000 \mathrm{~Hz} 8000 \mathrm{~Hz}$

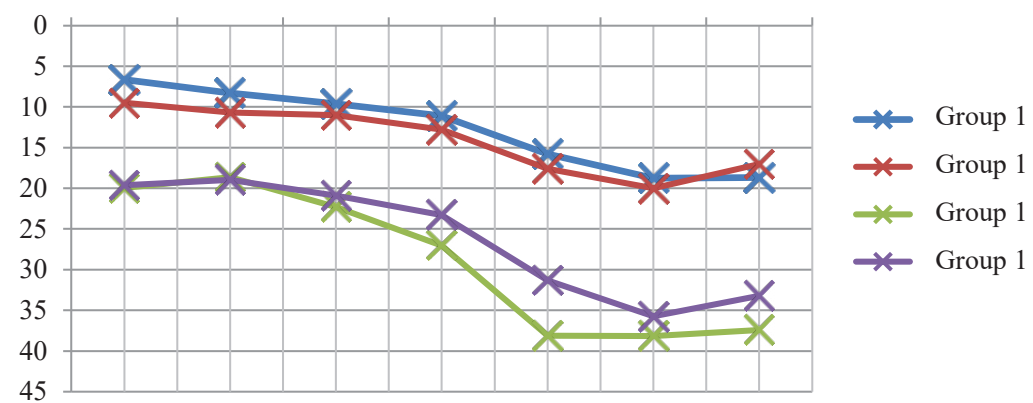

Fig. 7. Bone conduction thresholds in patients with AOM
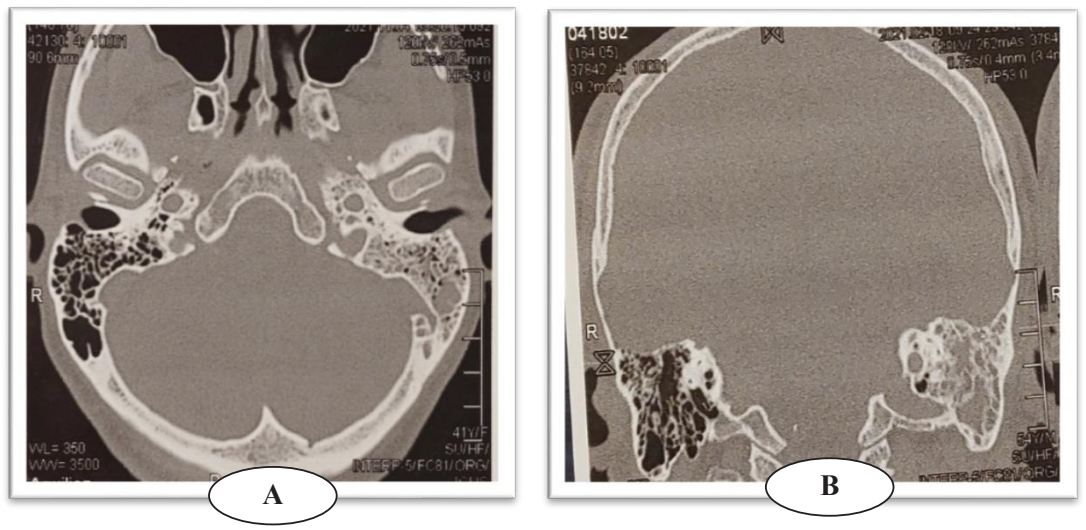

Fig. 8. Spiral computed tomography of patients with AOM against the background of impaired glucose metabolism in axial (A) and coronal (B) projections 
According to the results of CT examination of the temporal bones in patients with impaired carbohydrate metabolism, tympanopuncture and paracentesis were performed in $40.5 \%$ of cases in group 3 and in $44.7 \%$ of patients in group 4 . Shunting of the tympanic membrane was performed in $26.3 \%$ of cases against the background of impaired glucose metabolism and in $21.6 \%$ of patients with DM type II. $10.8 \%$ of patients with DM type II underwent surgical treatment - antromastoidotomy. At the same time, before the operation, tomograms showed no signs of destruction of bone trabeculae, and intraoperatively, softening of the bone was found in the absence of abundant purulent contents.

\section{Discussion of the results}

The study, systematization and analysis of the available clinical indicators revealed the presence of features of the course of acute otitis media in patients with impaired carbohydrate metabolism.

The main clinical feature is the discrepancy between the duration of the disease history, complaints and objective data on the state of the cellular structure of the mastoid process and auditory function, primarily the increase in the thresholds of perception of bone conduction sounds. The presence and nature of changes in the mastoid process according to CT examination of the pyramids of the temporal bones, a deeper lesion of sound perception with an intact, often cloudy tympanic membrane with fuzzy contours, indicate the likelihood of the formation of latent mastoiditis, taking into account the characteristics of bone metabolism inherent in diabetes mellitus. Against this background, complaints about a feeling of «heaviness» and periodic short-term pain in the behind-the-ear region acquire clinical significance, which, in the absence of reactive phenomena, are often regarded as neuralgia, especially in older patients, which includes most patients with impaired carbohydrate metabolism.

It has been established that objective symptoms of protrusion of the posterior and posteriorupper parts of the tympanic membrane, the presence of perforation in these quadrants, which often indicate the state of the cellular system of the mastoid process, and which should be taken into account in the differential diagnosis of latent mastoiditis, have diagnostic value.

The absence of statistically significant differences in laboratory parameters and audiometry data in patients of groups 1 and 2, as well as groups 3 and 4, testifies in favor of the pathogenetic significance of carbohydrate metabolism disorders for the formation of AOM course features. At the same time, the unreliability of the difference in the indices of patients in the 3rd and 4th groups indicates the significance of transient hyperglycemia even in the absence of diabetic complaints and a confirmed diagnosis of diabetes mellitus. This fact is confirmed by a statistically significant increase in the content of glucose and glycosylated hemoglobin in the blood in patients of the 4 th group compared with patients of the 1 st and 2 nd groups $(p<0.05)$. The established strong correlation between blood glucose and glycated hemoglobin against the background of inflammation of the middle ear structures in patients with DM type II and the presence of a correlation (albeit weak) in patients with transient hyperglycemia allow us to consider the determination of glycated hemoglobin as an informative criterion for diagnosing a complicated course of AOM.

Since the presence of type 1 diabetes mellitus was not detected in any of the cases, we can speak about the significance of DM type II in the pathogenesis of AOM.

The adverse effect of the comorbid background in patients with impaired carbohydrate metabolism is manifested by significant changes in individual (leukocytes, eosinophils, monocytes) indicators of the morphological composition of peripheral blood against the background of an increase in the level of endogenous intoxication, in particular RNR and LII Kalf-Kalif in the fourth group.

Study limitations. The study is limited to a certain specific time interval (2020), during which the main sample array was conducted and reliable results were obtained. The limitation of the study is the exclusion of a certain category of patients from it due to the presence of contraindications for CT examination, diagnostic measures.

Prospects for further research is to study the features of bone metabolism in patients with impaired carbohydrate metabolism and to identify diagnostically and clinically significant markers. It is also promising to develop a clinical diagnostic algorithm for determining an effec- 
tive AOM treatment strategy, taking into account the possibility of developing latent mastoiditis in patients with impaired carbohydrate metabolism and the previously studied clinical portrait of patients with DM type II [29].

\section{Conclusions}

Taking into account the obtained statistical data, patients over 18 years of age with AOM as the main diagnosis make up 6.2-7.2 \% of all nosological forms of ENT diseases in the hospital, while the proportion of acute otitis media among all ear diseases was significantly higher and ranged from $17.3 \%$ to $30.3 \%$. At the same time, patients with AOM in $16.1 \%$ of cases were previously diagnosed with DM type II.

In patients with AOM, 2 types of carbohydrate metabolism disorders can be distinguished: DM type II and transient hyperglycemia without diabetic complaints and anamnesis. Clinically and pathogenetically significant is not only persistent disorders of carbohydrate metabolism (established diagnosis of DM type II), but also transient hyperglycemia, therefore, such patients should be isolated from the contingent of patients with AOM for examination and treatment. Significant signs of transient hyperglycemia in patients with AOM should include even a single increase in peripheral blood glucose, the presence of glucose and (or) protein in the urine, an increase in the level of glycated hemoglobin, and a burdened endocrinological history.

Disturbance of carbohydrate metabolism contributes to the emergence and maintenance of a certain premorbid background, which forms the prerequisites for the development of latent mastoiditis, which is indicated, among other things, by changes in the composition of peripheral blood, leukocyte indices, and a deterioration in the function of sound perception in AOM against the background of impaired glucose metabolism.

Diagnostic significance in patients with AOM against the background of carbohydrate metabolism disorders are complaints of pain and a feeling of «heaviness» in the behind-the-ear region in the absence of reactive phenomena, complaints of a feeling of «pulsation» in the ear, dizziness, the presence of a cloudy tympanic membrane with protrusion or perforation in the posterior or posterior-upper sections, asymmetric increase in the thresholds of perception of bone conduction sounds above $25 \mathrm{~dB}$.

«Early» CT examination, taking into account diagnostically significant symptoms, will allow choosing an effective individually directed tactics for the treatment and rehabilitation of patients.

\section{Conflict of interests}

The authors declare that they have no conflicts of interest.

\section{Financing}

The study was performed without financial support.

\section{Acknowledgments}

The authors express their gratitude to the head of the Department of Otolaryngology and Pediatric Otolaryngology of the KhMAPE, professor Garyuk G.I. for support and valuable comments at all stages of work, as well as to the director of KNP «CCH No. 30» KCC Samusenko S. A. for the opportunity to conduct the research.

\section{References}

[1] Pochuieva, T. V., Filatova, H. A., Filatova, I. V., Iievleva, V. I. (2022) Patohenetychna znachymist hiperhlikemii u formuvanni osoblyvostei perebihu hostroho serednoho otytu ta yoho uskladnen. Mizhnarodnyi medychnyi zhurnal.

[2] Khoruzhyi, I. V. (2015). Patomorfolohichne ta kliniko-biokhimichne obgruntuvannia taktyky likuvannia hostroho serednoho otytu uskladnenoho sensonevralnoiu pryhlukhuvatistiu. Ternopil: Ternopilskyi natsionalnyi medychnyi universytet, 143. Available at: http://www.iol.com.ua/article/khoruziy_dis.pdf

[3] Rijk, M. H., Hullegie, S., Schilder, A. G. M., Kortekaas, M. F., Damoiseaux, R. A. M. J., Verheij, T. J. M., Venekamp, R. P. (2021). Incidence and management of acute otitis media in adults: a primary care-based cohort study. Family Practice, 38 (4), 448-453. doi: http://doi.org/10.1093/fampra/cmaa150 
[4] Pochuieva, T. V. (2014). Features of otoneurological state in the patients with acute otitis media and purulent meningoencephalitis in recovery. Zhurnal vushnykh, nosovykh i horlovykh khvorob, 3, 8-16. Available at: http://www.lorlife.kiev.ua/ 2014/2014_3_08.pdf

[5] Govea-Camacho, L. H., Pérez-Ramírez, R., Cornejo-Suárez, A., Fierro-Rizo, R., Jiménez-Sala, C. J., Rosales-Orozco, C. S. (2016). Diagnosis and treatment of the complications of otitis media in adults. Case series and literature review. Cirugía y Cirujanos, 84 (5), 398-404. doi: http://doi.org/10.1016/j.circir.2015.05.052

[6] Park, J. H., Park, S. J., Kim, Y. H., Park, M.-H. (2013). Sensorineural hearing loss: a complication of acute otitis media in adults. European Archives of Oto-Rhino-Laryngology, 271 (7), 1879-1884. doi: http://doi.org/10.1007/s00405-013-2675-x

[7] Elzinga, H. B. E., van Oorschot, H. D., Stegeman, I., Smit, A. L. (2021). Relation between otitis media and sensorineural hearing loss: a systematic review. BMJ Open, 11 (8), e050108. doi: http://doi.org/10.1136/bmjopen-2021-050108

[8] Yang, Q., Zhao, Y., Wang, Z. Y., Yu, Y. J., Zhang, W., Wang, W. Q. et. al. (2019). Progress in middle ear dysventilation research. Zhonghua Er Bi Yan Hou Tou Jing Wai Ke Za Zhi, 54 (4), 303-306. doi: http://doi.org/10.3760/cma.j. issn.1673-0860.2019.04.014

[9] McCoul, E. D., Weinreich, H. M., Mulder, H., Man, L.-X., Schulz, K., Shin, J. J. (2020). Utilization of Invasive Procedures for Adult Eustachian Tube Dysfunction. Otolaryngology-Head and Neck Surgery, 163 (5), 963-970. doi: http://doi.org/ $10.1177 / 0194599820931467$

[10] Gurov, A. V., Levina, Y. V., Guseva, A. L., Elchueva, Z. G., Efimova, S. P., Gordienko, M. V. (2018). The specific microbiological and clinical features of acute otitis media. Vestnik Otorinolaringologii, 83 (1), 36-39. doi: http://doi.org/10.17116/ otorino201883136-39

[11] Vergison, A. (2008). Microbiology of otitis media: A moving target. Vaccine, 26, G5-G10. doi: http://oi.org/10.1016/ j.vaccine.2008.11.006

[12] Bezeha, M. Y. (2016). Etiopatohenetychnyi pidkhid do vedennia patsiientiv z hostrym zapalenniam struktur serednoho vukha. Problemy ekolohii ta medytsyny, 20 (3-4), 9-13. Available at: https://ecomed-journal.org/index.php/journal/article/view/21

[13] Marchioni, D., Mattioli, F., Alicandri-Ciufelli, M., Presutti, L. (2013). Prevalence of ventilation blockages in patients affected by attic pathology: A case-control study. The Laryngoscope, 123 (11), 2845-2853. doi: http://doi.org/10.1002/lary.24165

[14] Bezeha, M. I. (2018). Improvingthe efficacy treatment of patients with acute otitis media, complicated by mastoiditis, using modified conservative and surgical techniques. Kyiv: Instytut otolarynholohii natsionalnoi akademii nauk Ukrainy im. prof. O. I. Kolomiichenka, 186. Available at: http://www.iol.com.ua/article/bezega_dis.pdf

[15] Li, Y., Chen, Y., Yin, G., Zeng, X. (2019). Effect of balloon dilation eustachian tuboplasty combined with tympanic tube insertion in the treatment of chronic recurrent secretory otitis media. European Archives of Oto-Rhino-Laryngology, 276 (10), 2715-2720. doi: http://doi.org/10.1007/s00405-019-05512-7

[16] Havrylenko, Yu. V. (2014). Actual problems of modern diagnostics and ENT-organs treatment of children and adults with diabetes. Zhurnal vushnykh, nosovykh ta horlovykh khvorob, 3, 44-50. Available at: http://www.lorlife.kiev.ua/2014/ 2014_3_44.pdf

[17] Shydlovska, T. A., Kostitska, I. O., Navalkivska, N. Ya. (2019). Stan slukhovoi funktsii u khvorykh na tsukrovyi diabet II typu. Zhurnal vushnykh, nosovykh ta horlovykh khvorob, 2, 88-89.

[18] Biryukova, E. V., Gurov, A. V., Yushkina, M. A. (2012). Diabetes mellitus and pyoinflammatory diseases of ENT organs. Diabetes Mellitus, 15 (2), 54-59. doi: http://doi.org/10.14341/2072-0351-5519

[19] Gurov, A. V., Yushkina, M. A. (2018). The peculiar features of the microbial paysage and the problems of antibacterial therapy of the inflammatory ENT diseases in the patients presenting with diabetes mellitus. Vestnik Otorinolaringologii, 83 (1), 59-61. doi: http://doi.org/10.17116/otorino201883159-61

[20] Popov, N. N., Gariuk, G. I., Filatova, I. V., Ognivenko, E. V. (2007). Kliniko-immunologicheskaia kharakteristika techeniia khronicheskogo gnoinogo verkhnecheliustnogo sinusita u bolnykh sakharnym diabetom. Mezhdunarodnyi meditsinskii zhurnal, 1, 103-107.

[21] Stern Shavit, S., Soudry, E., Hamzany, Y., Nageris, B. (2016). Malignant external otitis: Factors predicting patient outcomes. American Journal of Otolaryngology, 37 (5), 425-430. doi: http://doi.org/10.1016/j.amjoto.2016.04.005

[22] Marina, S., Goutham, M. K., Rajeshwary, A., Vadisha, B., Devika, T. (2019). A retrospective review of 14 cases of malignant otitis externa. Journal of Otology, 14 (2), 63-66. doi: http://doi.org/10.1016/j.joto.2019.01.003

[23] Chen, J.-C., Yeh, C.-F., Shiao, A.-S., Tu, T.-Y. (2014). Temporal Bone Osteomyelitis: The Relationship with Malignant Otitis Externa, the Diagnostic Dilemma, and Changing Trends. The Scientific World Journal, 2014, 1-10. doi: http://doi.org/ $10.1155 / 2014 / 591714$

[24] Chapman, P. R., Choudhary, G., Singhal, A. (2021). Skull Base Osteomyelitis: A Comprehensive Imaging Review. American Journal of Neuroradiology, 42 (3), 404-413. doi: http://doi.org/10.3174/ajnr.a7015 
[25] Singh, U., Venkitachalam, S., Chinnusamy, R. (2019). Clinical profiling and management outcome of atypical skull base osteomyelitis. British Journal of Neurosurgery, 34 (6), 686-689. doi: http://doi.org/10.1080/02688697.2019.1699905

[26] Knapp, S. (2013). Diabetes and Infection: Is There a Link? - A Mini-Review. Gerontology, 59 (2), 99-104. doi: http://doi.org/ $10.1159 / 000345107$

[27] Yamaguchi, T., Sugimoto, T. (2011). Bone metabolism and fracture risk in type 2 diabetes mellitus. Endocrine Journal, 58 (8), 613-624. doi: http://doi.org/10.1507/endocrj.ej11-0063

[28] Eller-Vainicher, C., Cairoli, E., Grassi, G., Grassi, F., Catalano, A., Merlotti, D. et. al. (2020). Pathophysiology and Management of Type 2 Diabetes Mellitus Bone Fragility. Journal of Diabetes Research, 2020, 1-18. doi: http://doi.org/10.1155/2020/7608964

[29] Pochuieva, T. V., Filatova, H. A., Filatova, I. V., Iievleva, V. I. (2022). Klinichnyi portret patsiienta iz tsukrovym diabetom 2 typu yak osnova formuvannia osoblyvoho perebihu hostroho serednoho otytu. Zhurnal vushnykh,nosovykh ta horlovykh khvorob.

Received date 21.12.2021

(C) The Author(s) 2022

Accepted date 24.01.2022

This is an open access article

Published date 31.01.2022 under the Creative Commons CC BY license

How to cite: Pochuieva, T., Filatova, A., Filatova, I. (2022). The impact of the COVID-19 pandemic, online-learning on the state of visual system and psychological state of students. EUREKA: Health Sciences, 1, 17-29. doi: http://doi.org/10.21303/ 2504-5679.2022.002280 